\title{
Drying of macaw palm fruits and its influence on oil quality
}

\section{Secagem em frutos de macaúba e sua inflûencia na qualidade do óleo}

\author{
Gutierres Nelson Silva ${ }^{1}$; Anderson Barbosa Evaristo ${ }^{2 *}$; \\ José Antonio Saraiva Grossi ${ }^{3}$; Larissa Sousa Campos ${ }^{4}$; \\ Marcela Silva Carvalho ${ }^{1}$; Leonardo Duarte Pimentel ${ }^{3}$
}

\begin{abstract}
After harvest, macaw palm fruits show high deterioration rates when improperly preserved. A possible cause is the high fruit water content favoring enzymatic and microbiological degradation. Therefore, this study aimed to evaluate the effect of drying on the mesocarp oil quality during storage and to set the drying curve of macaw palm fruits. For that, two experiments were carried out. In the first, the drying curve of macaw palm fruits was determined at $60^{\circ} \mathrm{C}$, and mathematical models were defined for the process. Drying was performed with freshly harvested fruits (S0) and with fruits stored for 20 days after harvest (S20). Fruits were stored for 20 days after harvested and then went through drying. The fruits were dried in a prototype dryer at $60{ }^{\circ} \mathrm{C}$. After drying, the fruits were stored for different periods $(0,15,30,45,60$, and 90 days) and evaluated for oil physicochemical parameters. When compared to S0, drying of macaw palm fruits in the S20 treatment showed a lower drying time until equilibrium moisture was reached. In general, all the mathematical models tested were adequate to describe the drying process. Fruits dried at $60{ }^{\circ} \mathrm{C}$ controlled mesocarp oil acidification for up to 90 days in storage. On the other hand, drying impaired the mesocarp oil oxidative stability. We may conclude that the drying process is efficient to maintain acidity during the storage of macaw palm fruits.
\end{abstract}

Key words: Acrocomia aculeate. Temperature. Mathematical models. Postharvest. Biodiesel.

\section{Resumo}

Frutos de macaúba apresentam elevada deterioração quando não conservados adequadamente após a colheita. Uma possível causa é o elevado teor de água nos frutos, o que pode favorecer a degradação enzimática e microbiológica dos frutos. Diante do exposto, objetivou-se com esse estudo avaliar o efeito da secagem na manutenção da qualidade do óleo do mesocarpo durante o armazenamento e determinar a curva de secagem de frutos de macaúba. Para isso, realizou-se dois experimentos. No primeiro, determinou-se a curva de secagem dos frutos de macaúba na temperatura de $60^{\circ} \mathrm{C}$ e definiu-se modelos matemáticos para o processo. A secagem foi realizada com frutos recém colhidos ( $\mathrm{S} 0$ ) e frutos armazenados durante 20 dias após a colheita (S20). Após a colheita os frutos foram armazenados durante 20 dias, após esse período foi realizado o processo de secagem. Os frutos foram secos em um secador protótipo a temperatura de $60^{\circ} \mathrm{C}$. Após a secagem, os frutos foram armazenados por diferentes períodos $(0,15,30,45,60$ e 90 dias) e avaliados quanto aos parâmetros físico-químicos do óleo. A secagem dos frutos de macaúba no tratamento S20, apresentou menor tempo de secagem até atingir umidade de equilíbrio comparado a S0. Em geral, todos os modelos matemáticos testados foram adequados para

\footnotetext{
Profs., Instituto Federal do Maranhão, IFMA, MA, Brasil. E-mail: gutierres.silva@ifma.edu.br; marcelasc.eng@gmail.com

2 Prof., Universidade Estadual do Tocantins, UNITINS, Palmas, TO, Brasil. E-mail: evaristo.ab@gmail.com

3 Profs., Universidade Federal de Viçosa, UFV, Viçosa, MG, Brasil. E-mail: jgrossi@ufv.br; leonardo.pimentel@ufv.br

4 Discente, UFV, Viçosa, MG, Brasil. E-mail: lari.scampos1@gmail.com

* Author for correspondence
} 
descrever o processo de secagem. Frutos secos a $60^{\circ} \mathrm{C}$ promoveu controle da acidificação do óleo do mesocarpo por até 90 dias em armazenamento. Por outro lado, a secagem prejudicou a estabilidade oxidativa do óleo do mesocarpo. Conclui-se que o processo de secagem é eficiente para viabilizar o armazenamento do fruto de macaúba sem o aumento da acidez.

Palavras-chave: Acrocomia aculeata. Temperatura. Modelos matemáticos. Pós-colheita. Biodiesel.

\section{Introduction}

There has been a growing demand for vegetable oils in recent years, mainly driven by increased consumption for feeding purposes in emerging countries, and the emergence of new industrial applications, notably biofuels (ROSILLO-CALLE et al., 2009).

The insertion of new oilseeds is an important strategy to increase production in the agricultural chains. The macaw palm [Acrocomia aculeata (Jacq.) Lodd. Ex Martius] is a promising species, since it is a perennial plant with high productivity of oils and lignocellulosic co-products, (EVARISTO et al., 2016). This palm is widely distributed in the Americas (MOURA et al., 2009), and has spherical fruits of the globular drupe type and yellowish color when ripe. The fruit consists of the fibrous peel (epicarp), oleaginous pulp (mesocarp), a nut (endocarp), and an oil-rich almond.

This species has a long fruiting period, and its harvest occurs between September and January (MONTOYA et al., 2016). This fact can cause a great obstacle to the industry, concentrating fruit processing in a small period of the year; therefore, storage would be a solution to the problem. The macaw palm fruit has a water content of approximately $40 \%$ (d.b.) at the time of harvest. This fact favors the growth and development of microorganisms during storage (CICONINI et al., 2013). These issues evidence the need to adopt postharvest strategies.

Drying is an important strategy for reducing water content. Heat and mass transfers must be well understood to reach a maximum efficiency, both economically and technically (COSTA et al., 2016). Therefore, the simulation and theoretical information related to the physiological, chemical, and physical variations of agricultural products are of paramount importance in the development, evaluation, and optimization of dryers. A satisfying mathematical model of the water loss should be used to simulate the drying of a particular product. These models may be empirical or phenomenological. Empirical models are generally simple and easy to apply since they are based on experimental data, dimensional and statistical analyses (COSTA et al., 2016). The phenomenological ones, however, are based on most complex theories and laws.

The sizing of a drying plant (KALETA; GÓRNICKI, 2010) and the prediction of a drying performance over time (BENNAMOUN; BELHAMRI, 2008) can be obtained through a drying mathematical simulation.

Although the potential of macaw palm to produce biofuels and bio-products is well known (CÉSAR et al., 2015), there is no information in the literature about mathematical models to predict the process and effect of drying on oil quality. In view of the above, the objective of this study was to propose and adjust mathematical models to the macaw palm fruits drying process, as well as to evaluate the effect of drying on the maintenance of the mesocarp oil quality during storage.

\section{Material and Methods}

This study was conducted in two stages. The first determined the drying curve and studied the mathematical modeling of macaw palm fruit drying. The second one evaluated the influence of drying in thin layer dryer and the mesocarp oil quality during fruit storage in a warehouse. 


\section{Fruit harvesting}

The macaw palm fruits were collected from plants growing in a natural population in the Zona da Mata (coastal plain) in the state of Minas Gerais, Brazil.

In the first experiment, fruits were collected from a rural property located in the municipality of Piranga, Minas Gerais (MG), while in the second experiment fruits were collected on a rural property in the municipality of Acaiaca - MG. The climate in the region is humid subtropical, with dry and cold winter, and hot rainy summer (Cwa-Köppen classification). The plants were previously identified, georeferenced, and monitored. Fruit bunches were harvested from the plant when the fruits were physiologically ripe and immediately transported to the laboratory. Fruits were selected after the harvest, with the removal of broken fruits and those with visible microorganism contamination.

Fruits were dried at the Department of Agricultural Engineering, and the pulp oil physicochemical properties were analyzed at the Biotechnology and Post-Harvest Laboratory of Macaw palm, both at the Federal University of Viçosa, Viçosa - MG.

\section{Experiment I}

A visual selection of the fruits was performed in the first experiment, and fruits showing signs of damage caused by microorganisms, insects, or physical damage were removed. Fruits were dried twice: right after harvest (S0), about 24 hours after harvest, and after 20 days of storage (S20). The fruits were stored in the laboratory $\left(25^{\circ} \mathrm{C}\right.$ and $70 \%$
$\mathrm{RH})$. This procedure was carried out to allow the accumulation of oil in the pulp, according to the results obtained by Goulart (2014). Fruit water content was determined by the standard oven method at $105 \pm 3{ }^{\circ} \mathrm{C}$ for $24 \mathrm{~h}$, in four replicates for each treatment (BRASIL, 1992).

The drying was performed in a laboratory scale dryer (atmosphere conditioning unit, manufactured by Aminco; model Aminco-Aire 150/300 CFM), at $60{ }^{\circ} \mathrm{C}$ and $60 \% \mathrm{RH}$. The mean process speed was 5.6 $\mathrm{m} \mathrm{s}^{-1}$. The trays containing the fruits were weighed periodically during the drying process using a 0.01 -g precision scale. Samples were weighed periodically during the drying process until mass variation between three consecutive weighings was equal to or less than $0.01 \mathrm{~g}$. The drying curve of the macaw palm fruits ( $\mathrm{S} 0$ and $\mathrm{S} 20$ ) was determined by the following equation:

In which:

$$
M R=\frac{W c-W e}{W o-W e}
$$

$\mathrm{MR}=$ Moisture ratio, dimensionless

$\mathrm{WC}=$ Water content at time $\mathrm{t}, \mathrm{kg}_{\mathrm{w}} \mathrm{kg}_{\mathrm{dm}}{ }^{-1}$

$\mathrm{W}_{0}=$ Initial water content, $\mathrm{kg}_{\mathrm{w}} \mathrm{kg}_{\mathrm{dm}}{ }^{-1}$

$\mathrm{W}_{\mathrm{e}}=$ Water content at the equilibrium point, $\mathrm{kg}_{\mathrm{w}}$ $\mathrm{kg}_{\mathrm{dm}}{ }^{-1}$.

The fruit drying data were adjusted in different mathematical models traditionally used to predict the drying phenomenon of agricultural products (Table 1). The best model was chosen on the following statistical parameters: mean square deviation (MSD), relative mean error $(P)$, and coefficient of determination $\left(\mathrm{R}^{2}\right)$. 
Table 1. Mathematical models used to predict the phenomenon of Macaw palm fruit drying.

\begin{tabular}{lll}
\hline Model name & Model equation & \\
\hline Henderson e Pabis & $\mathrm{MR}=\mathrm{a} \exp (-\mathrm{kt})$ & $(3)$ \\
Logaritmo & $\mathrm{MR}=\mathrm{a} \exp (-\mathrm{kt})+\mathrm{b}$ \\
Copace & $\mathrm{MR}=\left(\mathrm{a}+\mathrm{b}^{*} \mathrm{t}\right) /\left(1+\mathrm{ct}+\mathrm{dt}^{2}\right)$ & $(5)$ \\
Midilli & $\mathrm{MR}=\mathrm{a} \exp \left(-\mathrm{kt}^{\mathrm{n}}\right)+\mathrm{bt}$ & $(7)$ \\
Page & $\mathrm{MR}=\mathrm{a} \exp \left(-\mathrm{kt}^{\mathrm{n}}\right)$ & $(8)$ \\
Page Modificado & $\mathrm{MR}=\exp \left(\left(-(\mathrm{kt})^{\mathrm{n}}\right)\right)$ & $(9)$ \\
DoisTermos & $\mathrm{MR}=\mathrm{a} \exp (-\mathrm{kt})+\mathrm{b} \exp (-\mathrm{ft})$ & $(10)$ \\
Hang e Singh & $\mathrm{MR}=1+\mathrm{at}+\mathrm{bt} \mathrm{t}^{2}$ & $(11)$ \\
Aproximação de Difusão & $\mathrm{MR}=\mathrm{a} \exp (-\mathrm{kt})+(1-\mathrm{a}) \exp (-\mathrm{kbt})$ & $(12)$ \\
Newton & $\mathrm{MR}=\exp (-\mathrm{kt})$ & $(13)$ \\
Verna & $\mathrm{MR}=\mathrm{a} \exp (-\mathrm{kt})+(1-\mathrm{a}) \exp (-\mathrm{ft})$ \\
Exponencial de doistermos & $\mathrm{MR}=\mathrm{a} \exp (-\mathrm{kt})+(1-\mathrm{ah}-) \exp (-\mathrm{kat})$ & $(14)$ \\
\hline
\end{tabular}

In which: $\mathrm{a}, \mathrm{b}, \mathrm{c}, \mathrm{d}, \mathrm{f}$, and $\mathrm{n}=$ coefficients of the models, dimensionless, $\mathrm{k}=$ drying constant, $\mathrm{h}-1, \mathrm{t}=$ time, $\mathrm{h}$; and $\mathrm{MR}=\mathrm{moisture}$ ratio, dimensionless.

\section{Experiment II}

The fruits were harvested and soon after harvest the fungicide Tecto SC was applied, whose active ingredient is thiabendazole, at a concentration of $0.4 \% \mathrm{v} / \mathrm{v}$, using water as a vehicle. The fruits remained in the solution for two minutes, as recommended by the manufacturer.

After fungicide application, the fruits were stored for 20 days in the laboratory, at a temperature of $23{ }^{\circ} \mathrm{C}$. This procedure was based on the study of Evaristo et al. (2016), who suggested the climacteric behavior for macaw palm fruits, and recommended post-harvest fungicide treatment to maintain fruit oil quality for up to 20 days, during which there is a large accumulation of oil in the pulp. The fruits were then brought to a cross-flow, commercial scale prototype (thin layer drier). Mean air temperature was $60{ }^{\circ} \mathrm{C}$ during drying; mean air velocity was 5.6 $\mathrm{m} \mathrm{s}^{-1}$ with $65 \% \mathrm{RH}$, although the relative humidity varied greatly due to the climatic conditions during the experiment. The fruits were arranged in the dryer in six trays, each tray containing one layer of fruits (117 fruits). Drying was interrupted when the fruits reached approximately 9\% moisture (w.b.). The fruits from the drying treatment in thin layer dryer $\left(60{ }^{\circ} \mathrm{C}\right)$ and control treatment (stored at a constant temperature of $\left.23^{\circ} \mathrm{C}\right)$ were stored $(0,15,30,45,60$, and 90 days) in plastic boxes in a shed of masonry covered by zinc roof, and average temperature of $26{ }^{\circ} \mathrm{C}$.

Samples were taken according to storage times evaluated for quality and oil content analyses of the macaw palm fruits mesocarp. The following parameters were evaluated: mesocarp oil content (OC), acidityindex (AV), and oxidative stability (OS). OC was determined by nuclear magnetic resonance (NMR). The equipment MQC NMR Analyzer (Oxford brand) was used, following the method ISO 10565 (ISO, 1999). The AV was determined according to the Ca 5a-40 method (AOAC, 2005), converted to an oleic acid percentage. The OS was determined according to the method Cd 12b-92 (AOAC, 2005), using the equipment Rancimat ${ }^{\circledR}$ (model 873 BiodiselRancimat). The results were expressed in hours, and the induction period (IP) indicated the oxidative stability of the oil.

\section{Statistical analyses}

A non-linear regression analysis was performed for the adjustment of the mathematical models, using the Gauss Newton method and the STATISTICA $5.0 ®$ software. The second experiment was set up according to the $2 \times 6$ factorial scheme, with two 
treatments (drying at $60{ }^{\circ} \mathrm{C}$ and control), and six storage periods $(0,15,30,45,60$, and 90 days $)$, in a completely randomized design (CRD) with four replicates. The data were submitted to analysis of variance (5\% significance) and regression. Statistical differences were analyzed by the $\mathrm{F}$ test in the analysis of variance for the qualitative factor (drying temperature). Software R (2008) was used for the analyses of variance. The Sigma Plot Software was used for graph plotting in both experiments

\section{Results and Discussion}

\section{Experiment I}

Drying curve

The water content before the drying process of macaw palm fruits for the treatments S0 and
S20 were $74.67 \pm 3.33 \%$ and $51.66 \pm 2.4 \%$ (d.b.), respectively. Figure 1A shows the drying curves describing the behavior of macaw palm fruits in treatments S0 and S20. Drying occurred in two stages in both treatments. In the first one, there was a rapid reduction in fruit water content; the water content reduction continued in the second one, but more slowly, until reaching equilibrium moisture at $96 \mathrm{~h}$ and $114 \mathrm{~h}$ for the treatments S20 and S0, respectively. Silva et al. (2006) studied the drying kinetics of Macadamia integrifólia and detected water content reduction at the beginning of a fast drying process; this reduction was then slower and gradual, until reaching equilibrium. The mesocarp has almost half the fruit mass (CICONINI et al., 2013). In addition, the fibrous, fleshy nature and high mucilage content (REIS et al., 2012) contribute to the more pronounced water loss in this constituent part of the fruit.

Figure 1. Drying curves of macaw palm fruits submitted to drying soon after harvest (S0), and 20 days after harvest (S20) at $60^{\circ} \mathrm{C}(\mathrm{A})$, and drying curve of macaw palm fruits in thin layer dryer at $60^{\circ} \mathrm{C}(\mathrm{B})$. MR, moisture ratio.

A.

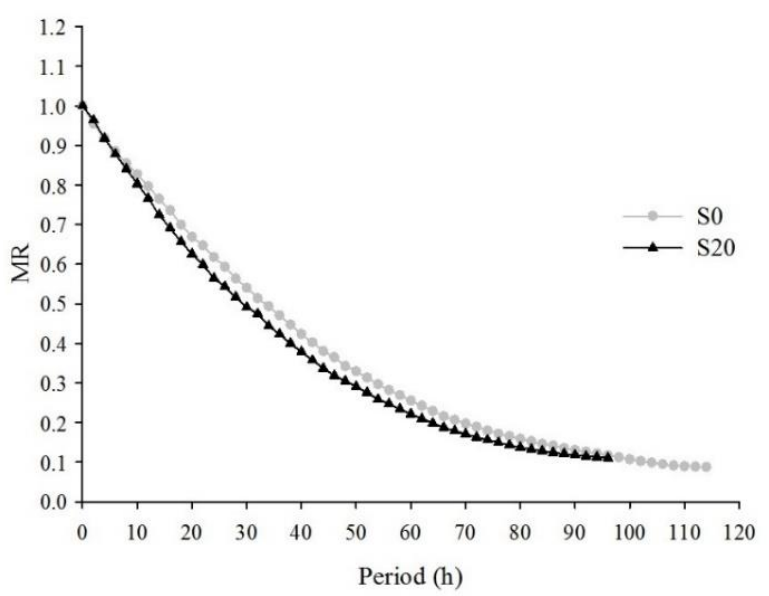

Regarding drying time, the average period for reaching the equilibrium water content in the fruits exposed to drying at $60^{\circ} \mathrm{C}$ was observed to be lower in treatment S20 (96 h) compared to treatment S0 (114 h). The energy consumed during the drying
B.

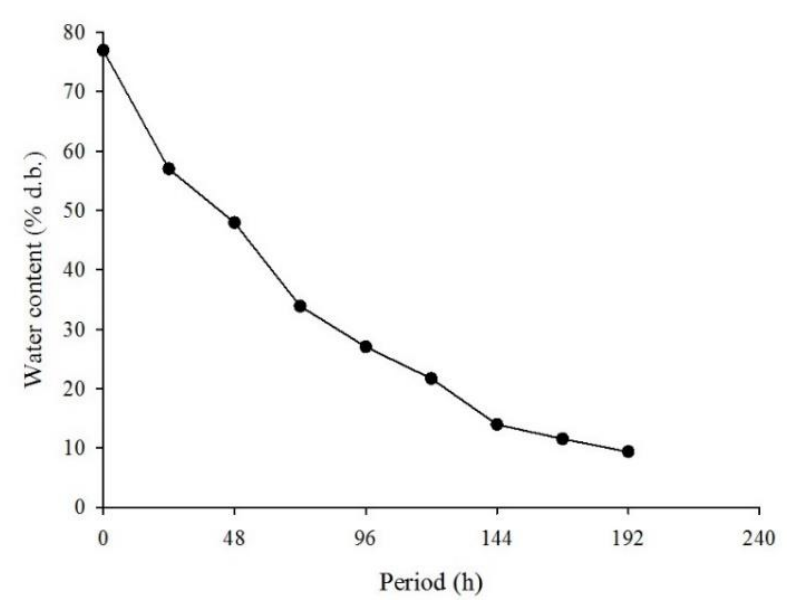

process of agricultural products is generally high. In this context, the drying of the macaw palm fruits only after 20 days of storage becomes an alternative to reduce the energy demand by the drying process. 


\section{Mathematical modeling}

Table 2 presents the adjustments and statistical parameters used to compare the 12 drying models analyzed in the drying conditions at $60^{\circ} \mathrm{C}$ used in the S0 and S20 treatments. All models had $P$ values lower than 10\%. Mohapatra and Rao (2005) observed mean relative errors $(P)$ below 10\%, indicating a good adjustment for practical purposes. Siqueira et al. (2012) studied the drying kinetics in jatropha (Jatropha curcas L.) seeds at a temperature of $60{ }^{\circ} \mathrm{C}$, and also showed $P$ values lower than $10 \%$ for the models of Page $(P=2.0 \%)$, Midilli $(P=$ $1.7 \%)$, and Two-terms $(P=1.4 \%)$.

Table 2. Mean relative error $(P)$, mean square deviation (MSD), and coefficients of determination $\left(\mathrm{R}^{2}\right)$ for mathematical models of macaw palm fruit drying.

\begin{tabular}{ccccc}
\hline Model & Treatment & $\boldsymbol{P}$ & MSD & $\mathbf{R}^{\mathbf{2}}$ \\
\hline \multirow{2}{*}{ Henderson e Pabis } & S0 & 3.2961 & 0.0123 & 0.9989 \\
& S20 & 3.8716 & 0.0078 & 0.9995 \\
Logaritmo & S0 & 4.3047 & 0.0113 & 0.9991 \\
& S20 & 2.9274 & 0.0078 & 0.9995 \\
Midilli & S0 & 1.0270 & 0.0044 & 0.9999 \\
& S20 & 1.4249 & 0.0042 & 0.9998 \\
Copace & S0 & 1.8838 & 0.0053 & 0.9998 \\
& S20 & 2.0355 & 0.0054 & 0.9997 \\
Page & S0 & 3.7382 & 0.0080 & 0.9995 \\
& S20 & 2.8406 & 0.0070 & 0.9965 \\
Page Modificado & S0 & 3.7382 & 0.0080 & 0.9995 \\
& S20 & 2.8406 & 0.0070 & 0.9996 \\
Dois Termos & S0 & 3.2960 & 0.0012 & 0.9999 \\
& S20 & 2.5713 & 0.0063 & 0.9997 \\
Hang e Singh & S0 & 5.1864 & 0.0109 & 0.9996 \\
Aproximação de Difusão & S20 & 3.6977 & 0.0104 & 0.9992 \\
& S0 & 3.1959 & 0.0070 & 0.9997 \\
Newton & S20 & 3.4116 & 0.0103 & 0.9992 \\
& S0 & 4.5565 & 0.0154 & 0.9983 \\
Verna & S20 & 3.4116 & 0.0103 & 0.9992 \\
& S0 & 4.8389 & 0.0117 & 0.9990 \\
Exponencial de dois termos & S20 & 2.5703 & 0.0063 & 0.9997 \\
& S0 & 3.3742 & 0.0103 & 0.9993 \\
& S20 & 3.4116 & 0.0103 & 0.9992 \\
\hline
\end{tabular}

Right after harvest (S0), about 24 hours after harvest, and after 20 days of storage (S20).

Regardless of the treatment (S0 and S20), all models had a high coefficient of determination $\left(\mathrm{R}^{2}\right)$ values, always higher than 0.99 . Corroborating with this study are the results obtained by Kashaninejad et al. (2007) when evaluating the models of Page and Henderson and Pabis to describe the thinlayer drying behavior of pistachio nuts at $55{ }^{\circ} \mathrm{C}$. In general, they observed $\mathrm{R}^{2}$ values above 0.99 for these two models.
In relation to the MSD parameter, the smaller the MSD value, the better the representation of the used model. The lowest MSD values for the S0 treatment were observed in the Two-terms and Midilli models. For the S20 treatment, the Midilli model presented the lowest MSD value. Ertekin and Yaldiz (2004) studied eggplant drying and found lower MSD values for the Midilli model under all drying conditions, as observed here. 


\section{Experiment II}

Figure $1 \mathrm{~B}$ shows the drying curve describing the behavior of macaw palm fruits at a temperature of $60{ }^{\circ} \mathrm{C}$ in thin layer dryer. The fruits started the drying process with $76 \%$ (d.b), requiring 8 days of drying to reach a moisture content of $9.4 \%$ (d.b). In the first three days, there was a higher drop in fruit water content of $43 \%$ of water, reaching a moisture of $34 \%$ (d.b). In the first 24 hours of drying, there was a $22 \%$ reduction in moisture. After this period, water loss was slow and, on average, there was a reduction of about $5 \%$.day ${ }^{-1}$ of fruit moisture.

The drying times between experiments I and II were distinct, however, the water loss behavior in both studies was similar, i.e. at the beginning, there was a rapid water loss and then slower loss. Several factors can influence the drying of agricultural products, such as the type of dryer, operating conditions, and the nature of the food submitted to the process (SILES et al., 2015; HELDMAN; HARTEL, 2000). In addition to this, the fruits of the two experiments were collected in different places, resulting in fruits with different morphological and physiological characteristics, and consequently different drying times. Some data may also justify these results: water content before the drying process $(52.13 \%$ d.b., $76.00 \%$ d.b., experiment 1 and 2 respectively); the number of fruits used in each experiment (120 and 702 fruits, experiment 1 and 2 respectively).

After the harvest (S0), even though there was an increase of $7 \%$ in OC with treatment (S20), the mesocarp oil content (OC) was on average $41.9 \%$ (Table 3). The effect of drying $\mathrm{x}$ storage was significant $(\mathrm{F}=2.828, \mathrm{p}=0.02968)$ but the drying temperature in storage at 0 days was only significant for interaction breakdown $(F=7.33 \mathrm{p}=0.0103)$.

Table 3. Of the analysis of the macaw palm fruits, mesocarp oil after harvest (S0) and 20 days after harvest (S20).

\begin{tabular}{lc}
\hline Analyzes & Sampling period \\
S0 S20 \\
\hline Oil content (\% d.b.)* & $41.95 \pm 0.38^{* *} 49.58 \pm 2.48$ \\
Acidity index (\% oleic acid) & $0.60 \pm 0.031 .35 \pm 0.2$ \\
Oxidative stability (h) & $13.59 \pm 0.8016 .94 \pm 0.27$ \\
\hline
\end{tabular}

$*$ d.b $=$ dry basis; $* *$ means \pm standard error.

After harvesting ( $\mathrm{S} 0$ ), the mean $\mathrm{AV}$ of macaw palm fruit oil was $0.6 \%$, and 20 days after harvest (S20), the content increased by about $0.7 \%$ (Table 3 ). As with oil content, the effect of drying and storage was significant for AV $(\mathrm{F}=19.482, p<0.00001)$ (Figure 2). Significant differences between treatments (drying and control) were observed only 45 days after storage. Drying at $60{ }^{\circ} \mathrm{C}$ kept the AV close to $1.5 \%$ throughout the fruit storage period.
Figure 3 depicts the AV behavior of the macaw palm fruits exposed to the control treatment in the different storage periods ( $\mathrm{F}=39.30, p<0.0001)$. An increase in $\mathrm{AV}$ is observed with the increase in the fruit storage period. No significant differences in AV were observed for the fruits exposed to the drying treatment in the different storage periods ( $\mathrm{F}$ $=0.0056, \mathrm{p}=1)$. 
Figure 2. Mean values of mesocarp oil content \% (A), acidity index \% in oleic acid (B), and induction period h (C) of macaw palm fruits exposed to drying treatments in thin layer dryer $\left(60^{\circ} \mathrm{C}\right)$ and control (room temperature), with different storage days (SD). Means with asterisks indicated a significant difference between the treatments (drying and control) by the $\mathrm{F}$ test $(P<0.05)$.
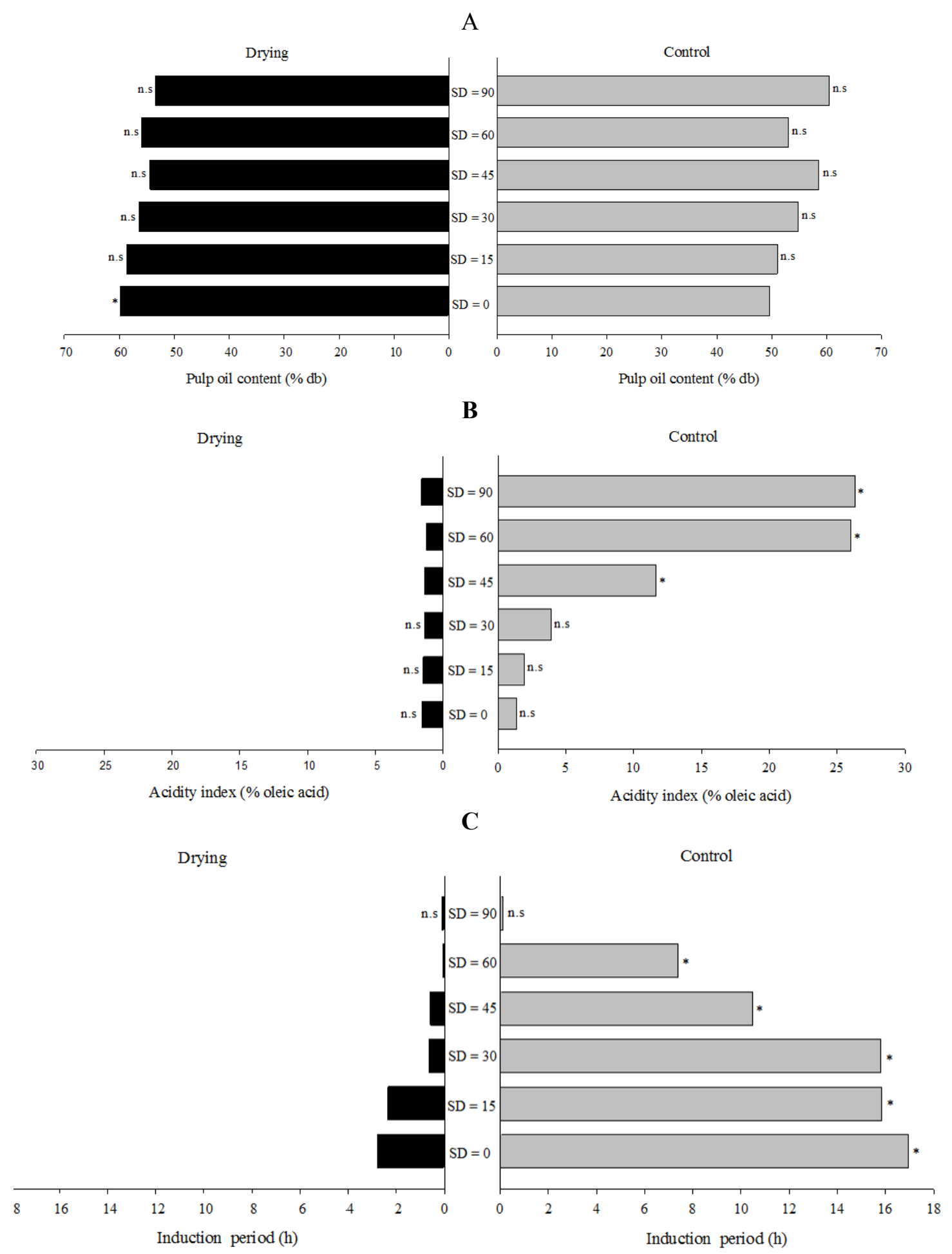
Figure 3. Acidity index \% (A) and induction period h (B) of macaw palm fruits exposed to room temperature (control) during storage.

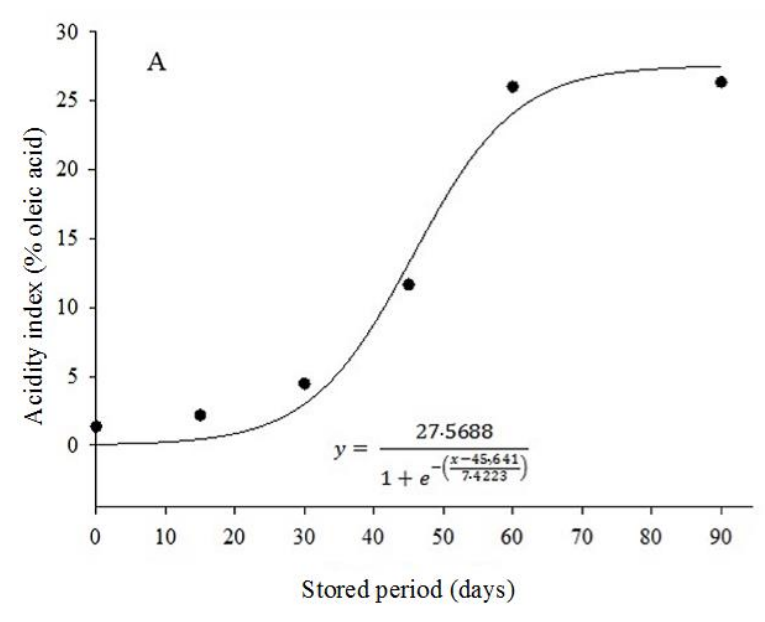

Drying the fruits at $60{ }^{\circ} \mathrm{C}$ inhibits the oil acidification process and the release of free fatty acids. This inhibition occurs mainly by reducing the water content. The drying process decreases the material water activity, causing enzyme denaturation, which minimizes or prevents the development of the microorganisms, promoting greater control in the progression rate of the acidity index during storage (BASTOS; OLIVEIRA, 2008).

The IP of the fruits mesocarp oil S0 was, on average, 13.6 hours and, at the end of the 20 days, there was an increase to $16.0 \mathrm{~h}$ (Table 3). The interaction between drying and storage was significant $(\mathrm{F}=5.615, p=0.000633)$ for PI. Figure 2 shows the mean values of oxidative stability over the fruit storage period for both treatments. Up to 60 days of storage, the control treatment presented higher oxidative stability values, i.e. lower oil degradation process, when compared to the treatment with thin layer dryer. Since the first evaluation in storage (day 0 ), there was a great loss of the oil oxidative stability in the fruits dried at $60^{\circ} \mathrm{C}$. After 30 days of storage, the mesocarp oil was totally oxidized, IP equal to $0 \mathrm{~h}$.

Figure 3 describes the IP behavior of the macaw palm fruits exposed to the control treatment in the

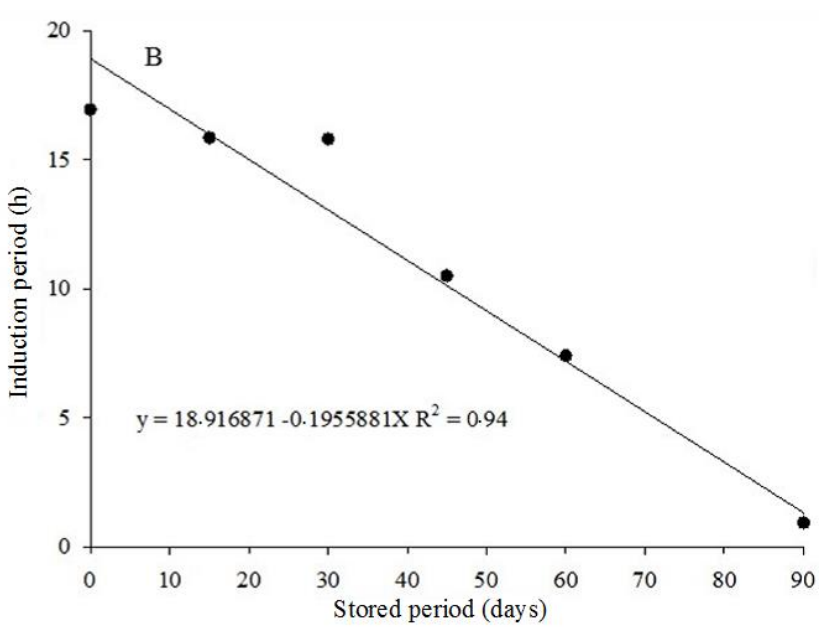

different storage periods. The IP of macaw palm fruits exposed to the control treatment decreased, increasing fruit storage period. There was no significant variation of the IP throughout storage for treatments with fruit drying at $60^{\circ} \mathrm{C},(\mathrm{F}=04803, p$ $=0.7885)$.

Regarding the drying process, there is a reduction in the mesocarp oil oxidative stability after fruit drying. Drying, mainly drying at high temperatures, favors physicochemical reactions due to the removal of water from protective hydration of the reactive sites, promoting approximation between the molecules, increasing the interaction between them. Water removal promotes the formation of microcapillaries in the fruit pulp, facilitating the physical contact of atmospheric oxygen, which together with the drying temperature, increases the rate of chemical reactions of oxidation and hydrolysis, affecting stability (MORETTO; FETT, 1998; BOBBIO; BOBBIO, 2001; ARAÚJO, 2004).

\section{Conclusion}

Compared to the S0 treatment, the drying of macaw palm fruits in the S20 treatment showed a lower drying time until reaching equilibrium 
moisture. In general, all mathematical models were adequate to describe the drying process in both treatments. As for the mesocarp oil quality, the drying at $60{ }^{\circ} \mathrm{C}$ is efficient for the storage of macaw palm fruits, keeping oil acidity low. However, it impairs the mesocarp oil oxidative stability.

\section{Acknowledgements}

The authors acknowledge Petrobras SA for financing the project, and also CAPES and CNPq for granting scholarships. Our acknowledgements to Dr. João Araújo (Fazenda Capela) and Cristiano Lana (Fazenda São Miguel) for the support and availability of the fruit collection areas, and to Prof. Juarez de Sousa e Silva for the technical support.

\section{References}

ARAÚJO, J. Química de alimentos: teoria e prática. In. . Oxidação de lipídios em alimento. Viçosa: UFV, 2004. p. 9-75.

ASSOCIATION OF OFFICIAL ANALYTICAL CHEMISTS - AOAC. Official methods of analysis of the Association of Official Analytical Chemists. Gaithersburg: Association of Official Analytical Chemists, 2005.

BASTOS, M. S.; OLIVEIRA, V. Ferramentas da ciência e tecnologia para a segurança dos alimentos. Fortaleza: Embrapa Agroindústria Tropical: Banco do Nordeste, 2008. $440 \mathrm{p}$.

BENNAMOUN, L.; BELHAMRI, B. Mathematical description of heat and mass transfer during deep bed drying: effect of product shrinkage on bed porosity. Applied Thermal Engineering, Ostrander, v. 28, n. 17, p. 2236-2244, 2008.

BOBBIO, P. A.; BOBBIO, F. O. Química do processamento de alimentos. 3. ed. São Paulo: Liv. Varela, 2001. 143 p.

BRASIL. Ministério da Agricultura e Reforma Agrária. Regras para análise de sementes. Brasília: MARA, 1992. $365 \mathrm{p}$.

CÉSAR, A. S.; ALMEIDA, F. A.; SOUZA, R. P.; SILVA, G. C.; ATABANI, A. E. The prospects of using Acrocomia aculeata (macaúba) a non-edible biodiesel feedstock in Brazil. Renewable and Sustainable Energy Reviews, Golden, v. 49, n. 1, p. 1213-1220, 2015.
CICONINI, G.; FAVARO, S.; ROSCOE, R.; MIRANDA, C.; TAPETI, C.; MIYAHIRA, M.; BEARARI, L.; GALVANI, F.; BORSATO, A.; COLNAGO, L. Biometry and oil contents of Acrocomiaaculeata fruits from the Cerrados and Pantanal biomes in Mato Grosso do Sul, Brazil. Industrial Crops and Products, Maastricht, v. 45, n. 9, p. 208-214, 2013.

COSTA, C. F.; CORREAA, P. C.; VANEGAS, J. D. B.; BAPTESTINI, F. M.; CAMPOS, R. C.; FERNANDES, L. S. Mathematical modeling and determination of thermodynamic properties of jabuticaba peel during the drying process. Revista Brasileira de Engenharia Agrícola e Ambiental, Campina Grande, v. 20, n. 6, p. 576-580, 2016.

ERTEKIN, C.; YALDIZ, O. Drying of eggplant and selection of a suitable thin layer drying model. Journal of Food Engineering, Essex, v. 63, n. 3, p. 349-359, 2004.

EVARISTO, A. B.; GROSSI, J. A. S.; CARNEIRO, A. D. C. O.; PIMENTEL, L. D.; MOTOIKE, S. Y.; KUKI, K. N. Actual and putative potentials of macauba palm as feedstock for solid biofuel production from residues. Biomass and Bioenergy, Aberdeen, v. 85, n. 1, p. 18-24, 2016.

GOULART, S. M. Amadurecimento pós-colheita de frutos de macaúba e qualidade do óleo para a produção de biodiesel. 2014. Dissertação (Mestrado em Fitotecnia) - Universidade Federal de Viçosa, Viçosa, MG.

HELDMAN, D. R.; HARTEL, R. W. Principles of food processing. New York: Chapman \& Hall, 2000. 218p.

INTERNATIONAL ORGANIZATION FOR STANDARDIZATION - ISO. In: ISSO 10565 oilseeds simultaneous determination of oil and moisture contents method using pulsed nuclear magnetic resonance spectrometery. Geneva: International Organization for Standardization 1999.

KALETA, A.; GÓRNICKI, K. Some remarks on evaluation of drying models of red beet particles. Energy Conversion and Management, Oxford, v. 51, n. 12, p. 2967-2978, 2010.

KASHANINEJAD, M.; MORTAZAVI, A.; SAFEKORDI, A.; TABIL, L. G. Thin-layer drying characteristics and modeling of pistachio nuts. Journal of Food Engineering, Essex, v. 78, n. 1, p. 98-108, 2007.

MOHAPATRA, D.; RAO, P. S. A thin layer drying model of parboiled wheat. Journal of Food Engineering, Essex, v. 66, n. 4 , p. 513-518, 2005.

MORETTO, E.; FETT, R. Tecnologia de óleos e gorduras vegetais na indústria de alimentos. São Paulo: Varela, 1998. $150 \mathrm{p}$. 
MONTOYA, S. G.; MOTOIKE, S. Y.; KUKI, K. N.; COUTO, A. D. Fruit development, growth, and stored reserves in macauba palm (Acrocomia aculeata), an alternative bioenergy crop. Planta, Heidelberg, v. 244, n. 4, p. 927-938, 2016.

MOURA, E. F.; MOTOIKE, S. Y.; VENTRELLA, M. C.; DE SÁ JÚNIOR, A. Q. S. Somatic embryogenesis in macaw palm (Acrocomiaaculeata) from zygotic embryos. Scientia Horticulturae, Amsterdam, v. 119, n. 4, p. 447-454, 2009.

R DEVELOPMENT CORE TEAM. R: a language and environment for statistical computing. R Foundation for Statistical Computing, Vienna, Austria, 2008.

REIS, S. B.; MERCADANTE-SIMÕES, M. O.; RIBEIRO, L. M. Pericarp development in the macaw palm Acrocomia aculeata (Arecaceae). Rodriguésia, Rio de Janeiro, v. 63, n. 3, p. 541-549, 2012.
ROSILLO-CALLE, F.; PELKMANS, L.; WALTER, A. A global overview of vegetable oils, with reference to biodiesel. Paris: IEA Bioenergy Task 40, 2009. 89 p. Available at: <http://www.globalbioenergy.org/ uploads/ media/0906_IEA_Bioenergy_-_A_global_overview_ of_vegetable_oils_with_r eference_to_biodiesel.pdf $>$. Accessed at: 16 ago. $201 \overline{2}$.

SILVA, F. A.; MARSAIOLI JUNIOR, A.; MAXIMO, G. J.; SILVA, M. A. A. P.; GONÇALVES, L. A. G. Microwave assisted drying of macadamia nuts. Journal of Food Engineering, Essex, v. 77, n. 3, p. 550-558, 2006.

SIQUEIRA, V. C.; RESENDE, O.; CHAVES, T. H. Drying kinetics of Jatropha seeds. Revista Ceres, Viçosa, MG, v. 59, n. 2, p. 171-177, 2012.

SILES, J. A.; GONZÁLEZ-TELLO, P.; MARTÍN, M. A.; MARTÍN, A. Kinetics of alfalfa drying: Simultaneous Modelling of moisture content and temperature. Biosystems Engineering, Cambridge, v. 129, p. 185-196, 2015. 
